Article

\title{
Land Use as a Motivation for Railway Trespassing: Experience from the Czech Republic
}

\author{
Pavlína Skládaná *, Marek Havlíček, Ivo Dostál, Pavel Skládaný, Pavel Tučka and Jan Perůtka \\ Transport Research Centre, Líšeňská 33a, 63600 Brno, Czech Republic; marek.havlicek@cdv.cz (M.H.); \\ ivo.dostal@cdv.cz (I.D.); pavel.skladany@cdv.cz (P.S.); pavel.tucka@cdv.cz (P.T.); jan.perutka@cdv.cz (J.P.) \\ * Correspondence: pavlina.skladana@cdv.cz
}

Received: 21 November 2017; Accepted: 28 December 2017; Published: 3 January 2018

\begin{abstract}
Railway trespassing is a very risky but common behaviour, resulting in about 200 casualties annually in the Czech Republic. This study describes the formation of 27 selected risk localities with frequent occurrence of trespassing in the regions of southern, central and northern Moravia. To be able to describe the process, an evaluation of the development of land use was conducted within a wide spatial context of each spot. The evaluation was focused on functional use of built-up areas (collective and individual housing, industrial areas, shopping and services, recreational areas, etc.). In the sample of investigated localities were places of two kinds: (1) localities where the railway intersected existing settlement structures, and relationships and links within the area were radically disturbed and severed. A lack of legal possibilities for crossing restricts the movement of inhabitants at these localities; (2) localities where the railway originally passed through open landscape and was later surrounded by built-up areas with various land-use functions. Here, trespassing is the consequence of gaps in the urban-planning process, wherein the needs of pedestrians and cyclists were not sufficiently considered. The analysis of the development of land use since 1836 showed how the motivations of trespassing were gradually intensified with more and more complex structures of functional division of areas. The percentage of built-up areas increased in all monitored localities overall from $6.28 \%$ during $1836-1852$ to $52.15 \%$ during $2014-2015$.
\end{abstract}

Keywords: land use; railway trespassing; spatial planning; Czech Republic

\section{Introduction}

\subsection{Situation in the CzechRepublic}

Unauthorized entry to railway tracks constitutes a very serious, although often underestimated, problem of traffic safety. In the Czech Republic, the number of road accidents with pedestrians is generally considered to be alarming. Reckoning with the data of 2015 (131 pedestrians killed in road traffic [1]) and 55,738 $\mathrm{km}$ of registered motorways and main roads (Czech Statistical Office https://www.czso.cz/csu/czso/transport_infrastructure_time_series), the relative yearly number of casualties per $\mathrm{km}$ is 0.00235 . Including also $50,730 \mathrm{~km}$ of local roads (Czech Statistical Office https:/ / www.czso.cz/documents/10180/20535744/w-930609a02.pdf/5d1efda5-db5e-4355$920 \mathrm{~d} 1767 \mathrm{~b} 458286 \mathrm{a}$ ?version $=1.0)$, the number is 0.00123 casualties per $\mathrm{km}$. The length of railway in the Czech Republic is 9436 km (http:/ / www.szdc.cz/o-nas/zeleznice-cr/zeleznicni-sit-v-cr.html), with ca 200 pedestrian casualties every year, i.e., 0.0212 casualties per $\mathrm{km}$. The relative number of pedestrian casualties per $\mathrm{km}$ is, therefore, 17 times higher on the railways. Despite this fact, the problem is not systematically solved in practice. 


\subsection{Circumstances Contributing to Illegal Crossing and Types of Risk Localities}

The phenomenon of trespassing has been the subject of many studies, mostly concentrated on the consequences of trespassing (i.e., train-person crashes) and possibilities for their prevention. Trespass prevention has recently been elaborated systematically within the framework of the international project RESTRAIL [2,3]. An innovative approach can be found in a Finnish project using spatial analysis for the prevention of train-trespasser collisions [4].

Trespassing as such is the subject of two Finnish studies that, among other things, have revealed the frequency, motivations, and opinions of trespassers at selected problematic sites $[5,6]$. Taking a short cut was indicated to be the main reason for trespassing, while half of respondents believed that trespassing is safe and $15 \%$ considered trespassing to be legal. The desire to shorten the distance from point $A$ to point $B$ is mentioned also in other works as the prevailing motivation for trespassing [7-9]. Additional reasons include recreation (strolls, walking dogs), socializing, vandalism, theft, and risk-seeking [7,9].

Conditions most typically contributing to trespassing on railways were summarized by da Silva [10] and include the following: accessibility (in sufficient or no fencing, absence of landscaping, proximity to frequently visited destinations), poor visibility (site located behind a curve or bump, poor visibility from the nearest road), and the possibility to take a short cut to one's destination.

A Turkish study [11] cites as a crucial cause of trespassing and of a high number of train-person collisions the fact that a substantial proportion of the population lives at the peripheries of large municipalities in proximity to railways and without adequate pedestrian infrastructure. Under such circumstances, trespassing inevitably becomes an everyday activity.

A study from Brisbane in Australia has dealt with a similar issue [12]. Direct observations were conducted at three black spot urban level crossings to better understanding the personal motivations and characteristics of trespassers. The results confirmed that more transgressions should be observed in highly urbanized areas. Freeman [13] examined the origins of pedestrians' rule breaking behaviour at crossings, with particular emphasis directed towards examining the factors associated with making errors versus deliberation violations.

In the Czech Republic, the recently conducted research project AMELIA has described the current situation of railway trespassing in the country and provided an overview of basic preventive principles. Regarding locations and motives for trespassing, six types of risk localities were specified [14]: trespassing at stops and stations, everyday short cuts apart from stations (for these first two types, the dominant motivation is the effort to shorten the distance between points A and B); short cuts and lingering trails in recreation localities (in addition to shortening a tourist trail, the motivation here is also use of the space near rails or even railway infrastructure itself for recreational purposes); places of interest (e.g., urban explorers, railway enthusiasts, but also vandals and graffiti artists); places of meeting or lodging (places in proximity to railways sought out by users of alcohol and drugs or as hideaways for homeless people); and trespassing at level crossings (time saving as motivation).

\subsection{Aim of the Study}

Nevertheless, the broader historical, social, and urban context of railway trespassing has not been much elaborated to date, and particularly not in Europe. The fact that the character and frequency of trespassing, as well as the number of accidents, are influenced by a wide range of factors, including urban development, culture, and economics, was highlighted by Savage [15], who analysed historical data about train-person crashes in the United States. He proved that the number and character of crashes are influenced not only by demographic changes in the population and the progress of railway traffic but also by economic and political events.

This study brings together existing knowledge about trespassing motivations with data from topographic maps in order to determine the impact of land-use development on the formation of sites with frequent railway trespassing. Old topographic maps are used today mostly in connection with evaluating long-term land use [16-18]. Some rare studies investigating the influence of roads 
on historical development of land use may also be found [19]. On the other hand, the formation of settlements and its impact on transport infrastructure, namely in connection with urban planning, is a topic rather frequently examined [20-22]. These studies, however, concern mainly existing problems related to the growth of agglomerations in dynamically developing areas. Historical aspects are not usually examined. As a specific issue, relationships and links between the detailed structure of the landscape at roads and mortality of animals are monitored [23]. The development of railways and its impact on changes in settlement infrastructure and land use have been investigated only marginally in the Czech Republic [24]. Elsewhere, studies focusing on the historical context of railway network development and its impact on land use can be found $[25,26]$. The influence of physical barriers, including railways, on land-use patterns and socio-spatial differentiation within towns was emphasized also by Noonan [27]. The correlation between the development of settlement structures at railways and the emergence of trespassing is not commonly studied. More often, attention is given to issues of brownfield revitalization, where the relationships and links between the functional use of land and railway infrastructure are quite obvious, namely in towns [28-30].

The main purpose of this article is to describe how conflict points in urbanized areas are formed using available topographical maps, aerial images, and town plans within a wider spatial context and while considering functional land use (collective and individual housing, industrial areas, transportation, shopping and services, public services, public greenery, etc.). Furthermore, the study proves a hypothesis relating to the impact of railway construction on the development of settlements and restriction of land permeability for pedestrians:

(a) in cases of a railway intersecting an existing settlement structure; and

(b) in cases of a railway built apart from the historical settlement structure and then gradually surrounded by built-up areas with various use functions.

\section{Materials and Methods}

\subsection{Selection of Risk Localities and Field Surveys}

A sample of 27 existing risk points was selected to assess the role of urban development in the formation of conflict points at sites of frequent railway trespassing. Most of the chosen model localities had already been examined within the AMELIA project (Trespassing railway property-research of situation and proposal of measures for prevention and mitigation of consequences) [14] or were newly selected using the electronic map of train-person crashes [31], also produced within the AMELIA project.

The selection of the localities was carried out with the purpose of representing a wide variety of risk spots, regarding the motivations, environs, users, intensity of trespassing and the extents of risk. Based on a rough preliminary typology, the selection of suitable localities was grounded on several sources, one of which was the electronic map of train-person crashes. Although crashes often happen at places where railway trespassing occurs seldom or not at all (suicides, accidental entry by a disoriented person), a significant proportion is concentrated in the very points of frequent unauthorized entries. Many illegal short cuts are so highly frequented and trodden that the paths over or along the tracks are clearly visible from aerial maps. Usually, logical pedestrian links within the settlement can be found at such places.

It should be mentioned that even highly frequented short cuts may be still without an accident record, and thus these may not be found using the electronic map of crashes. On the other hand, these places are well known as risk points among railway personnel and sometimes also among local authorities. As an additional method for identifying conflict points, semi-structured interviews with dispatchers, engine drivers, railroad workers, police, and local authorities were carried out. Another valuable source of information consisted in the webpages of railway aficionados and urban explorers. These resources, however, revealed mainly localities sought out by interest groups (e.g., technical 
monuments), which are often very dangerous but not much used as logical pedestrian routes and thus not of much use for this study.

The study of the electronic maps of crashes, interviews with experts, and the search of webpages brought a record of ca 60 localities, of which 27 of the most suitable were chosen for the field survey. These included inspections, assessment of broader relationships, observation and count, as well as interviews with people living in close proximity or with users in order to define the main function of short cuts and reasons for trespassing. The information of function, layout, walkability, view conditions, intensity and speed of rail traffic, accidents, legal alternative, frequency and time distribution of trespassing was obtained for each locality [14].

For the purposes of this study, only those localities were selected where an everyday need for connection between functionally different parts of the city or area was the main motivation for trespassing; 20 such localities were chosen from the original set and 7 new localities were found and subjected to the same field survey. For a more detailed study of the links between the changes in land use and trespassing, locations in larger cities and locations on important railway lines were selected.

\subsection{Analysis of the Development of Land Use}

Old topographic maps (commencing from the middle of the 19th century) exploitable in GIS [16,17], old cadastral maps, old town plans, orthophotomaps, historical atlases of railways [32], and other relevant sources were used to assess the development of settlement structures.

For each locality, the development of functional land use and of the communication network was analysed separately for each part of a territory divided by a railway. A scale of ca 1:25,000 for close surroundings defined by walking distance $-1 \mathrm{~km}$ on both sides (or more in justified cases) —-was used for various time periods. The map sources were:

1836-1852: II. Austrian military mapping 1:28,800

1876-1880: III. Austrian military mapping 1:25,000

1953-1955: Czechoslovak military topographic maps 1:25,000 + archival orthophotomaps

1988-1991: Czechoslovak and Czech military topographic maps 1:25,000

2014-2015 (actual situation): current orthophotomap + basic topographic map 1:10,000

Categorization of the area was elaborated according to basic land-use categories following the methodology of land-use categorization based on old topographic maps of medium scale (see Mackovčin [33]): arable land, forest, permanent grassland, orchard and garden, vineyard and hop field, built-up area, recreational area, other area, water area. Changes in land use were analysed using layers of spatial objects created by vectorization over sets of old maps in the ESRI ArcGIS environment. When mapping the basic division of land use, the minimum mapping unit has a size of 0.8 ha.

The development of functional land use and spatial relationships in railway environs was evaluated on the basis of categories for functions of built-up areas as defined in Dostál et al. [34]: $\mathrm{BI}$-individual housing; $\mathrm{BH}$-collective housing; SX-poly functional areas (both commercial and residential); OK—shopping; OX-services, leisure activities (sports, public services, technical infrastructure); DX — transport infrastructure; VT—heavy industry and energetic; VL—light industry, craft business, assembly plants; VK-logistics and warehouses areas; VZ-agriculture farms; ZX-urban green spaces and parks; and RZ-recreational areas.

The mapped categories for functions of built-up areas are divided with respect to use and/or attractiveness as potential trip starting points or destinations in the territory. The collected data was then used to evaluate the potential for transport relationships and links for all localities in different time periods. The conditions for railway trespassing were determined by comparison and assessing the development of changes in trip starting point and/or destination potential. This resulted in the assignment of each locality to one of two respective types:

- $\quad$ railway introduced into existing spatial structures; or

- $\quad$ later urbanization of originally open landscape along an existing railway. 


\section{Results}

\subsection{Evaluation of the Historical Development of Land Use in Model Areas}

Based on the analysis from a previous project about railway trespassing in the Czech Republic, and using complementary analysis and field research, 27 localities were selected in the regions of Moravia and Silesia (Figure 1). Land use within a radius of ca $1 \mathrm{~km}$ from the problematic point on the railway was analysed for each locality. Old and current topographic maps from five time periods (1836-1852, 1876-1880, 1953-1955, 1988-1991, 2014-2015) were employed to study land use.

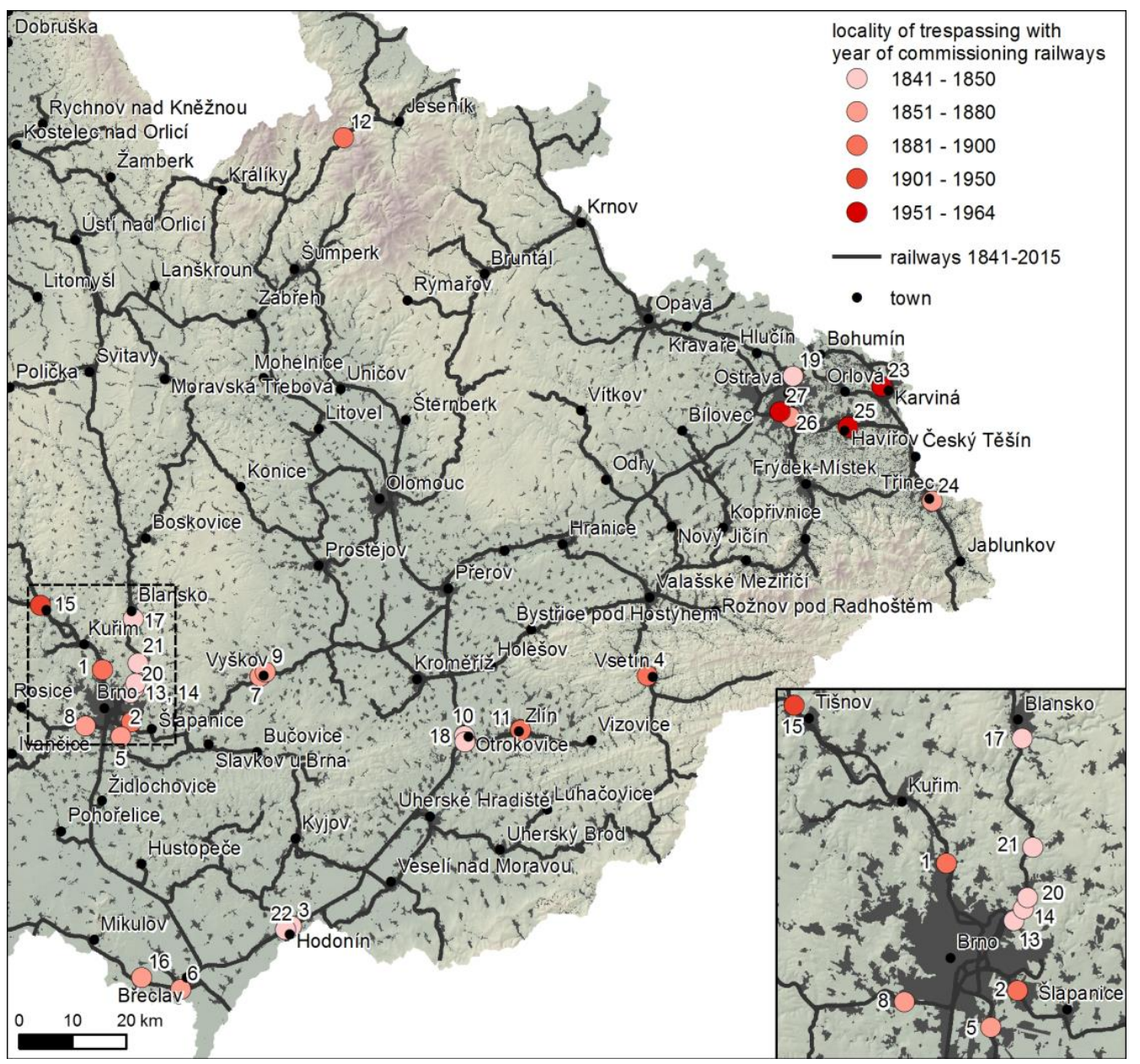

Figure 1. Surveyed localities for monitoring the development of land use in the vicinity of railway tracks: 1 Brno-Globus, Řečkovice (Mokrá Hora); 2 Brno-Slatina; 3 Hodonín-Na Výhoně; 4 Vsetín; 5 Brno-Holásky; 6 Boříles; 7 Vyškov-Jungmannova; 8 Brno-StarýLískovec; 9 Vyškov-Jiřího Wolkera; 10 Otrokovice-T. Bati; 11 Zlín-Dlouhá; 12 Ramzová; 13 Brno-Obřany; 14 Těsnohlídkovo údolí; 15 Tišnov-Trmačov; 16 Valtice; 17 Blanenský lom; 18 Otrokovice-Barum; 19 Ostrava-Hrušov; 20 Bílovice nad Svitavou; 21 Pod Ronovem; 22 Hodonín-nádraží; 23 Karviná; 24 Třinec; 25 Havířov; 26 Ostrava-Kunčice; 27 Ostrava-Vítkovice.

The maps were of medium scales $(1: 28,800,1: 25,000$, and 1:10,000), thus enabling long-term interpretation of land use within the basic categories arable land, permanent grassland, orchard and garden, vineyard and hop field, forest, water area, built-up area, recreational area, and other area.

Evaluation of long-term land use revealed several identical trends in all localities. Dynamic expansion of built-up areas in close vicinity to the railway related both to expansion of residential areas and growth of industry occurred during construction of the railway and building of stations (Table 1). 
Table 1. Area of basic land-use categories in hectares and percentage of area of 27 model sites.

\begin{tabular}{|c|c|c|c|c|c|c|c|c|c|c|}
\hline \multirow{2}{*}{$\begin{array}{c}\text { Year } \\
\text { Category }\end{array}$} & \multicolumn{2}{|c|}{$1836-1852$} & \multicolumn{2}{|c|}{$1876-1880$} & \multicolumn{2}{|c|}{ 1953-1955 } & \multicolumn{2}{|c|}{ 1988-1991 } & \multicolumn{2}{|c|}{ 2014-2015 } \\
\hline & ha & $\%$ & ha & $\%$ & ha & $\%$ & ha & $\%$ & ha & $\%$ \\
\hline Arable land & 6123 & 56.5 & 6564 & 60.6 & 4392 & 40.5 & 2032 & 18.7 & 1620 & 14.9 \\
\hline Permanent grassland & 2191 & 20.2 & 1316 & 12.1 & 647 & 6.0 & 556 & 5.1 & 618 & 5.7 \\
\hline Garden and orchard & 33 & 0.3 & 15 & 0.1 & 299 & 2.8 & 320 & 3.0 & 291 & 2.7 \\
\hline Vineyard and hop field & 33 & 0.3 & 26 & 0.2 & 49 & 0.4 & 114 & 1.1 & 85 & 0.8 \\
\hline Forest & 1764 & 16.3 & 1883 & 17.4 & 1934 & 17.8 & 2037 & 18.8 & 2106 & 19.4 \\
\hline Water area & 10 & 0.1 & 2. & 0.0 & 13 & 0.1 & 25 & 0.2 & 28 & 0.3 \\
\hline Built-up area & 681 & 6.3 & 1021 & 9.4 & 3352 & 30.9 & 5323 & 49.1 & 5653 & 52.2 \\
\hline Recreational area & 0 & 0.0 & 0 & 0.0 & 22 & 0.2 & 317 & 2.9 & 335 & 3.1 \\
\hline Other area & 6 & 0.1 & 12 & 0.1 & 133 & 1.2 & 116 & 1.1 & 105 & 1.0 \\
\hline Total & 10,840 & 100.0 & 10,840 & 100.0 & 10,840 & 100.0 & 10,840 & 100.0 & 10,840 & 100.0 \\
\hline
\end{tabular}

Some general trends in land use have been documented in other studies from the Czech Republic, such as a decrease in permanent grassland, gradual growth of forest areas, and decrease in water areas at the end of the 19th century $[17,18]$. Due to the selected sections of railway tracks being located primarily in urban areas, the most important process of change in land use was that of urbanization. The percentage of built-up areas increased in all monitored localities overall from $6.28 \%$ during 1836-1852 to 52.15\% during 2014-2015. In the case of recreational areas, gardening and cottage colonies in the hinterland of cities are included in this category. Such colonies, together with other built-up areas, constitute a crucial factor contributing to the occurrence of railway trespassing. Localities with prevailing tourism have the lowest proportion of built-up areas, such areas usually consisting of smaller holiday resorts.

In the territory of Moravia and Silesia, these trends in land use were similar across some categories from a long-term perspective. In proximity to the selected localities, however, they were more intense. The percentage of built-up areas, for example, increased across the territory of Moravia and Silesia from $2.7 \%$ to $7.8 \%$. Due to the inclusion of some localities with the presence of forest, a similar trend of forest-area growth appeared in the selected localities, as characterized throughout the territory by an overall rise from $28.5 \%$ to $37.8 \%$. Another general trend in Moravia and Silesia is a considerable decrease in permanent grassland, which also is documented in the 27 selected localities (Table 1).

Of all 27 evaluated localities, four localities with railway tracks were recorded on the maps of the second Austrian military mapping (opening of the railway occurred in ca 1841). In all four cases, railway track and railway stations and stops were located outside built-up areas of cities and towns. From this point of view, the original settlement structure was not disturbed.

At 15 monitored localities, the railway was opened between 1847 and 1872. Railway tracks and railway stations for this period were already recorded on topographic maps of the third Austrian military mapping from 1876-1880. They were often plotted manually on the maps from previous mappings, as well. Although the railway was mostly routed outside built-up parts of villages and towns, in three cases it led through built-up areas and original pedestrian relationships and links in the territory were disrupted. Specifically, these sites were Třinec, Ostrava-Kunčice, and Bílovice nad Svitavou.

During 1885-1905, railways were opened in five localities. Three of them (Vsetín, Tišnov, and Ramzová) entered existing built-up areas and impacted transport services and spatial relationships in those areas.

In the remaining three localities, the railway was opened in the late period of 1961-1964. In these localities (Haviŕrov, Karviná, and Ostrava-Vítkovice), the railway always entered built-up areas.

Research on land use in the regions where the railway was routed in close proximity to or through the periphery of a town indicated higher dynamics of built-up area growth. Land owners and investors took advantage of the convenient location near railway tracks and railway stations for building industrial complexes, including the possibility for connection to the railway network with the 
help of industrial tracks. In the case of routing the railway to existing built-up zones, no significant subsequent dynamics of development in built-up areas were documented. This was due to the fact that the railway was brought to cities with nearly completed urbanization or to smaller towns with a recreational character. On the other hand, the conditions for disturbing existing relationships in these settlements were ever greater.

Maps of historical land use and percentages of land-use categories were available for each of the 27 selected localities. The selected localities in Northern Moravia and Silesia may be described as very dynamic. Dynamic growth of built-up areas was connected with development of the mining, metallurgical, and manufacturing industries as well as general growth of settlements and concentration of the population. In other localities, the growth dynamics in built-up areas were not so great and other land-use trends were present, including development of recreational areas in the background of cities. For the purposes of this study, the historical evolution of land use was evaluated in more detail at six selected localities. Ostrava-Kunčice, Ostrava-Vítkovice, Karviná, and Třinec were chosen in the

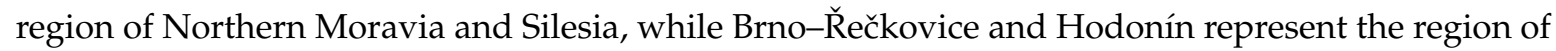
Southern Moravia.

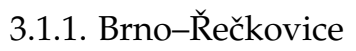

The model risk locality in Brno-řečkovice is one where the railway was established at the end of the 19th century (1885) and partly disturbed the relationships between the municipalities of Řečkovice and Mokrá Hora. Later growth of the Brno agglomeration caused important changes in landscape structure and proportions of land-use categories (Figure 2). The expansion of built-up areas, consisting in both housing and industry, and more recently including shopping areas, was very dynamic. Growth of recreational areas was also present, represented mainly by cottage colonies and gardens.

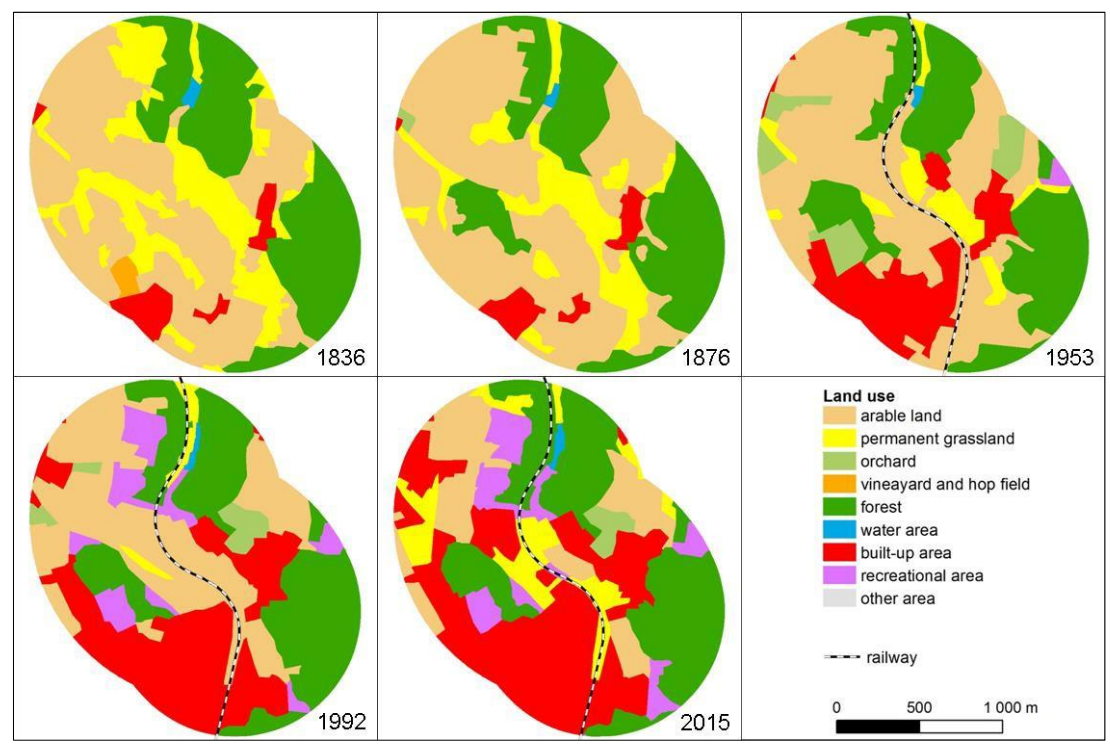

Figure 2. Development of land use and the railway network in Brno-̌̌ečkovice.

A high-risk site for railway trespassing is located at $\mathrm{km} 12.64$ of line no. 250 between the stops

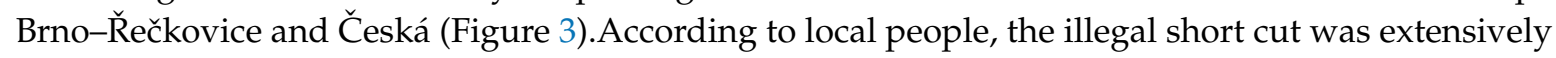
used in the past primarily for recreational purposes, but the frequency of trespassing increased sharply after construction of the Globus shopping centre and the Ivanovice Globus bus stop. In addition to the remaining recreational links, users living permanently in the neighbourhood as well as cottagers and gardeners shorten their way to and from the shopping centre or the bus stop. The nearest legal passage across the track is through an underpass located about $450 \mathrm{~m}$ away, which nevertheless addresses only pedestrian relationships from the eastern part of Mokrá Hora. For other users, it represents a considerable detour through aesthetically unattractive places. The occurrence of trespassers is 
continuous throughout the day, in the order of several individuals per hour, with higher frequency in the afternoons and on weekends.
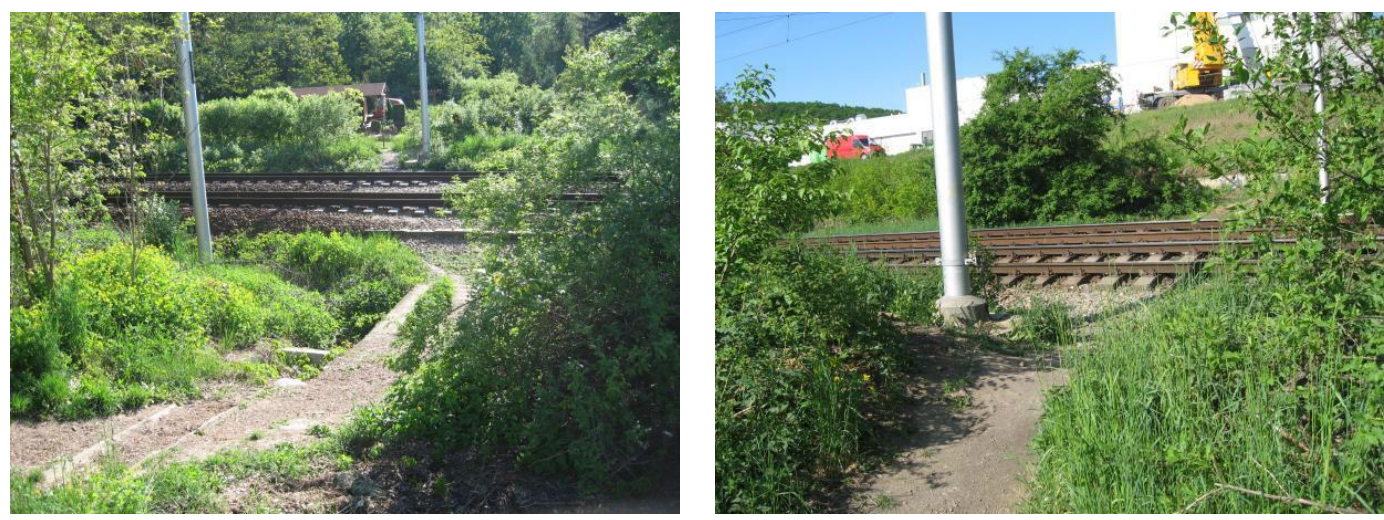

Figure 3. Site of frequent railway trespassing at the locality Brno-̌̌ečkovice.

\subsubsection{Hodonín}

The railroad was brought to Hodonín as early as 1841. It was one of the first railway lines on the territory of the modern-day Czech Republic. Land-use maps reveal an important change in land use especially regarding the growth of built-up areas in proximity to the railway station. Another limitation on pedestrian movement for local inhabitants was the opening of additional stages of the railroad in the direction of Zaječí and Holíc (Figure 4). The principal problem remains the inconsistency between the needs of the local population and the spatial planning at the highly trafficked Břeclav-Hodonín-Přerov railway.

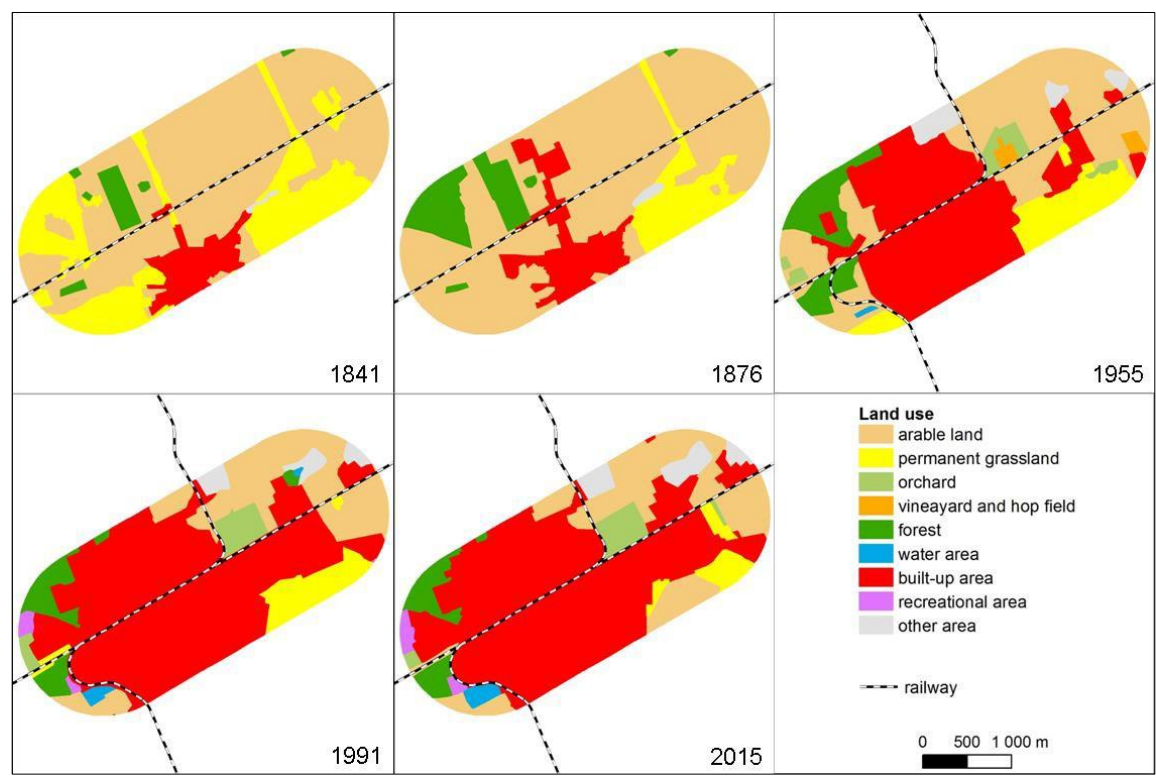

Figure 4. Development of land use and the railway network in Hodonín.

The Hodonín locality exemplifies a territory whose development was conditioned by introduction of the railway. After the railroad and railway station were put into operation, a brick-making industry developed in the northern part of the territory and a sugar factory and malt-house were opened near the railway station. Barracks were built for a local garrison in close proximity to the railway (see map from 1876, Figure 5). During the subsequent period, further industrial areas developed as well as colonies of workers' houses, other residential areas, and recreational areas. After the recent 
withdrawal of the military personnel and sugar factory, another change has occurred in the motivation for railway trespassing.

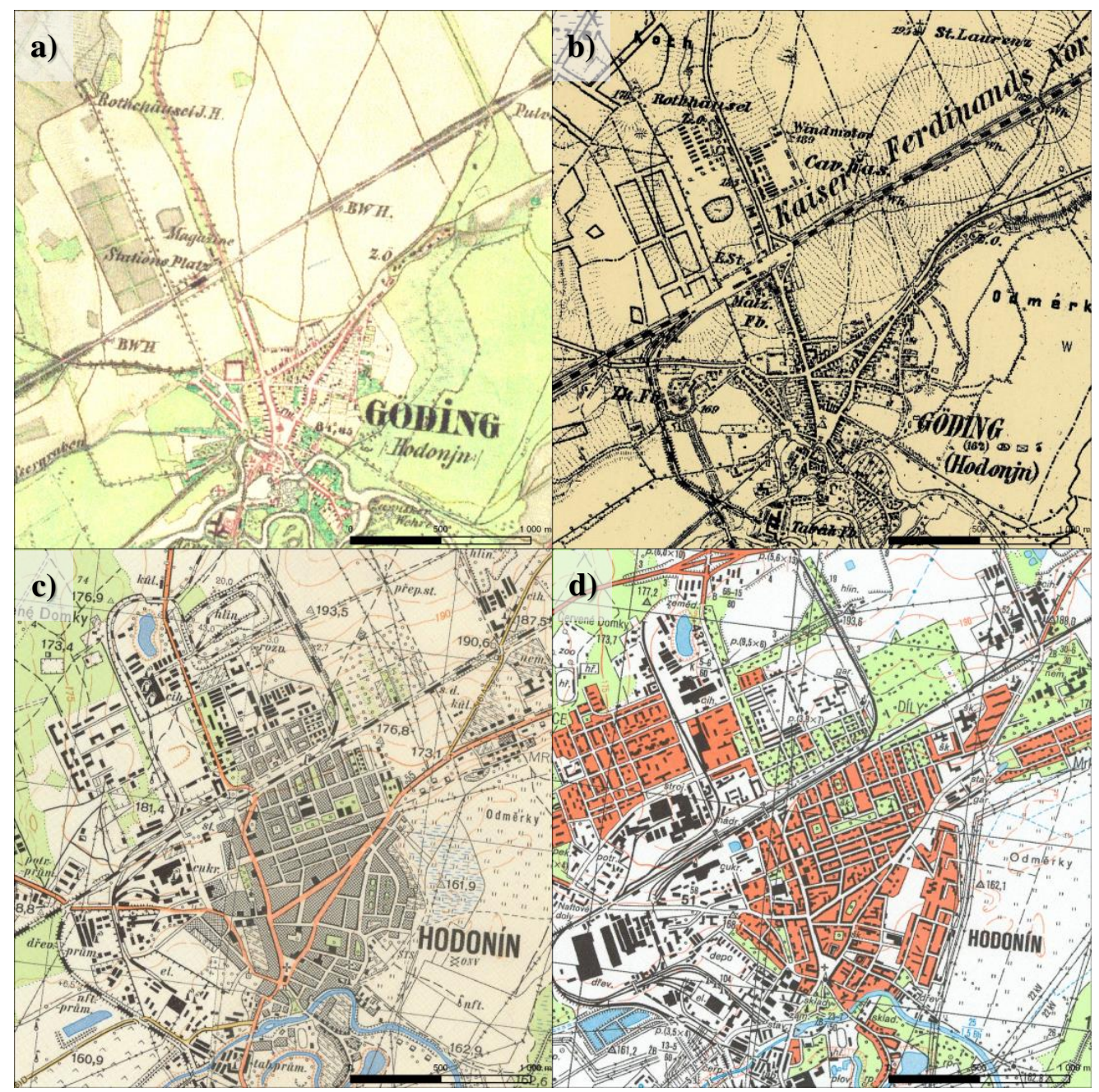

Figure 5. Old topographic maps of Hodonín from 1841 (a), 1876 (b), 1955 (c) and 1991 (d).

Railway trespassing in Hodonín is characterized by a series of illegal short cuts located mostly at emergency exits in noise barriers (Figure 6). The short cuts connect the industrial part, where collective housing is also located, with the centre of town (housing, services). The illegal paths are highly risky and not easily traversable, but frequently used.
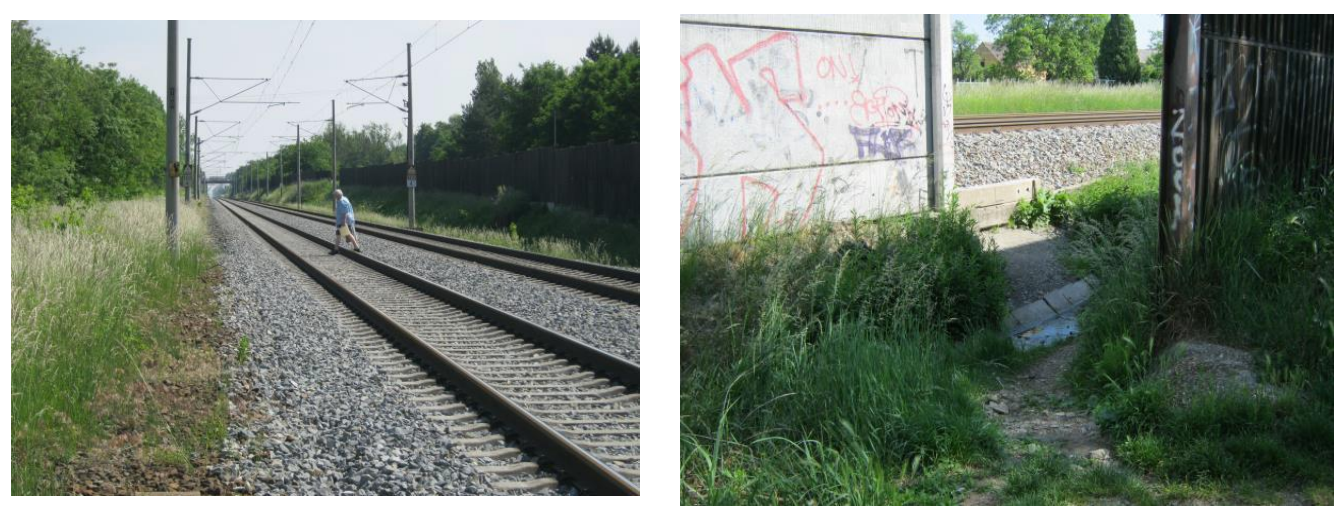

Figure 6. Railway trespassing in Hodonín. 


\subsubsection{Karviná}

Karviná is an important industrial town in Silesia whose development was closely related to a boom in coal-mining and other heavy and engineering industries. The respective railroad segment and railway station were not built until 1963, when the intensive growth of built-up areas (housing, industrial, and services) in the territory was already taking place (Figure 7). At the beginning of the monitored period (1839), the map shows margins of two built-up areas-the Old Town in the west and Fryštát in the east. The two settlements merged following gradual enlargement of built-up areas (see Figure 7, 1956), mainly due to the building of the New Town in the north-east. Construction of the railway in 1963 affected some of the existing spatial relationships, and these have not yet been optimally resolved in terms of urban planning. Built-up areas were set up mainly at the expense of arable land, permanent grassland, orchards and gardens.

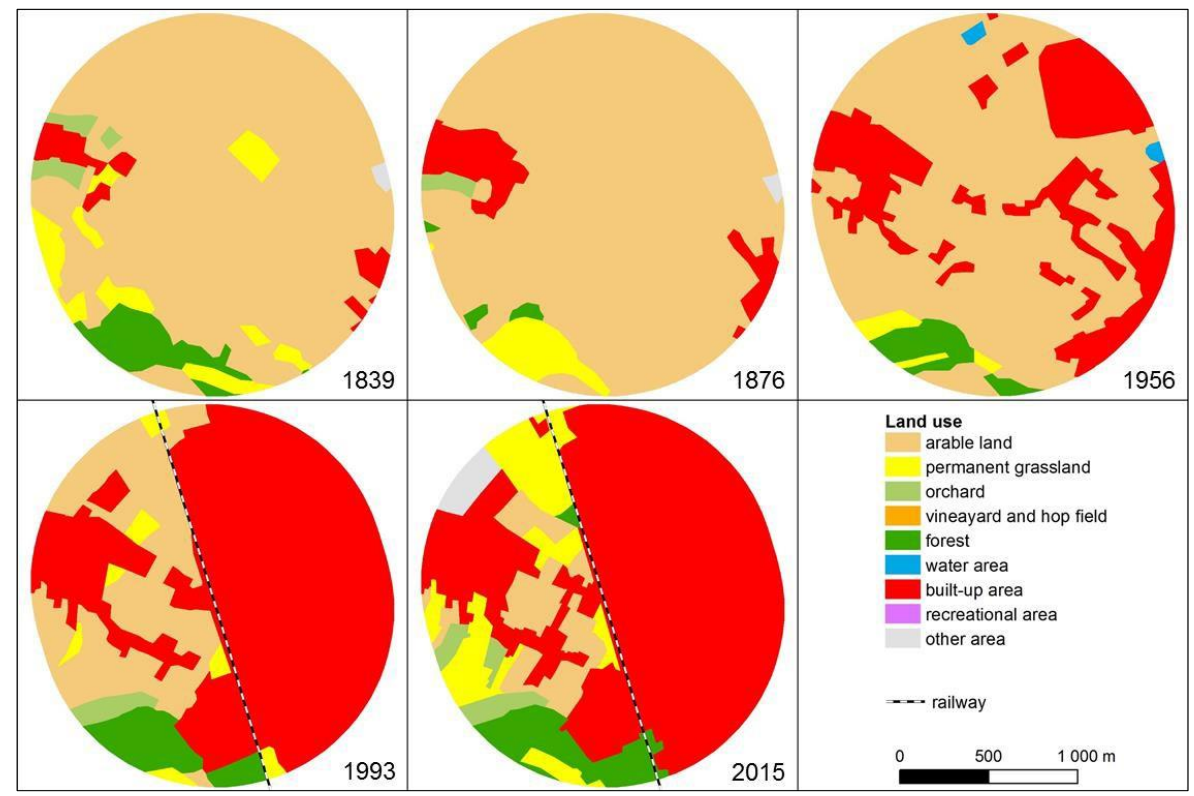

Figure 7. Development of land use and the railway network in Karviná.

An illegal short cut continues from the street "U tratě" (in English, literally "By the railway line") and connects the Old Town quarter with the Albert supermarket (after partial demolition, there is no shop in the Old Town) and the city centre. People use the short cut also on their way to the railway and bus stations. Walking across several tracks entails a high level of risk (Figure 8). The frequency of trespassing is about 10 cases per hour.
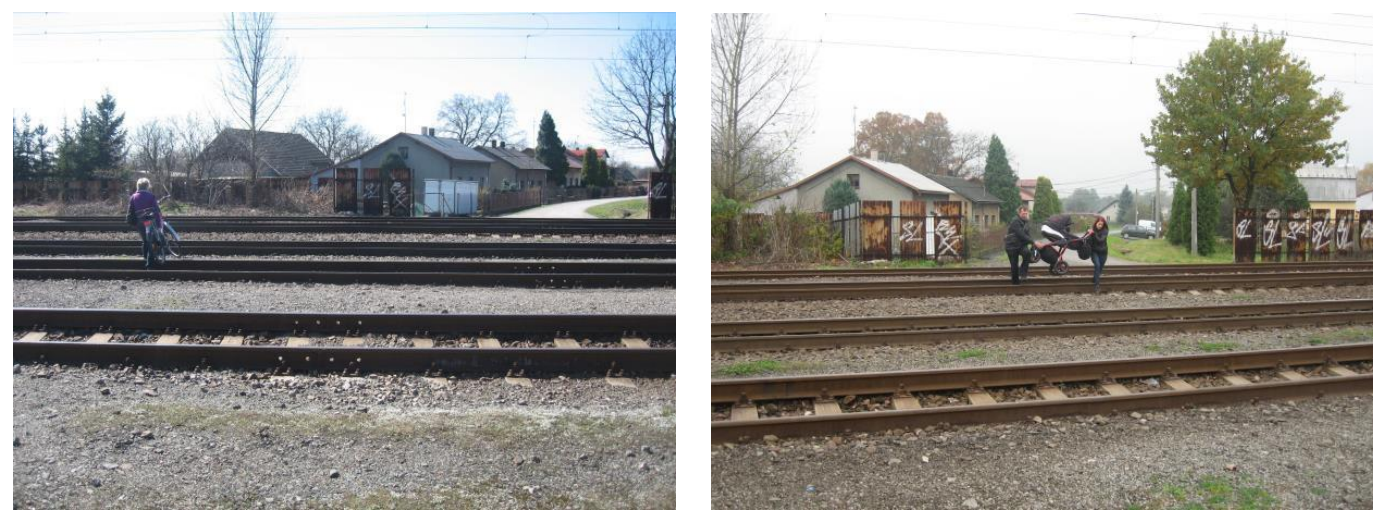

Figure 8. Trespassing in Karviná. 


\subsubsection{Ostrava-Vítkovice and Ostrava-Kunčice}

Vitkovice and Kunčice are, today, districts of the municipality of Ostrava. Both are characterized by a high proportion of industrial areas, namely steelworks, ironworks and coal-mines. The land-use map from 1876 already indicates a public railway for passenger transport in Kunčice (the eastern part), while no railway is shown in the territory of Vítkovice (the western part). Even in Vítkovice, however, the railway has been in operation since 1871, when an important ironworks was connected with the main railway by industrial tracks. In Kunčice, the railroad ways used for delivering raw materials to the local sugar refinery. In both localities, significant growth of built-up areas occurred at the end of the 19th century and in the first half of the 20th century (Figure 9). Industrial areas grew most, followed by colonies of workers' houses and later by collective housing and associated services. The complex of industrial, housing, and service areas created very difficult conditions for optimizing the railway crossing in Kunčice, and, in the context of urban planning, construction of the railway line in Vítkovice (1964) did not sufficiently take into account conditions for safe crossing.

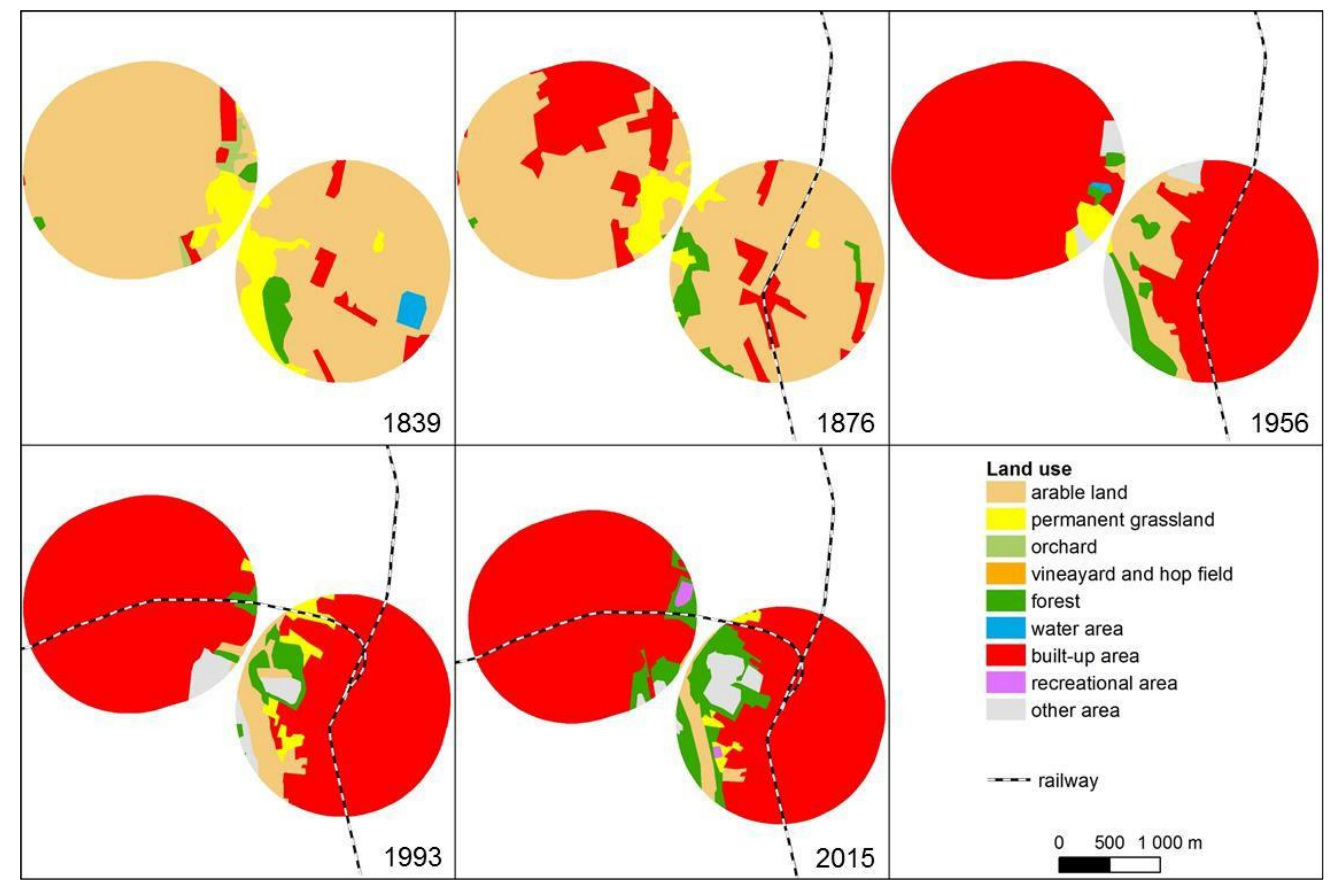

Figure 9. Development of land use and the railway network in Ostrava-Vítkovice and Ostrava-Kunčice.

In Ostrava-Kunčice, intensive and risky trespassing occurs across the large northern station head as a continuation of the street "U Sýpky" (in English, "At the granary"). The danger owes not only to the length of the short cut, but also to the necessity to cross movable parts of two switches and the very high intensity of railway traffic. Two important rail corridors (Český Těšín-Ostrava Svinov and Ostrava-Valašské Meziříčí) go through this area, and the large railway siding of the Arcelor Mittal steelworks is also connected. Mostly residential buildings (low-rise family houses) can be found on one side of the tracks and a large area of steelworks and some smaller enterprises on the other side. Interviews with trespassers confirmed that the shortcut is used mainly to travel to and from work. The legal alternative for crossing consists of an underpass beneath the railway station. It is more than $500 \mathrm{~m}$ from the logical route, is very long, neglected, and poorly illuminated, and itself raises safety concerns (Figure 10). 

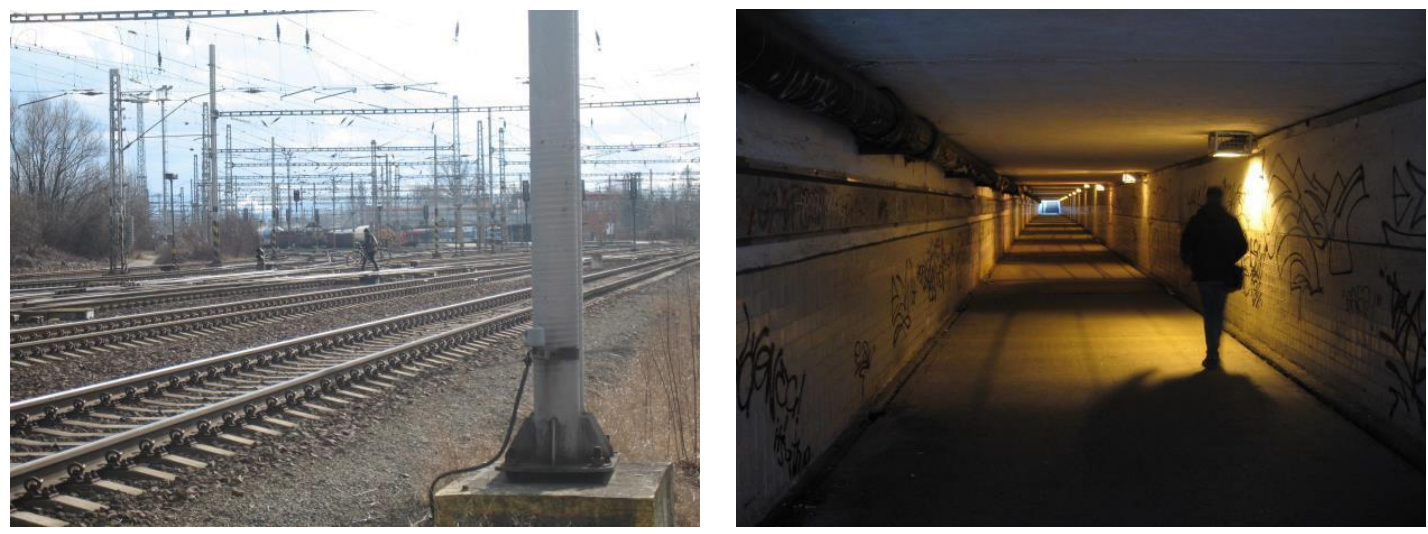

Figure 10. Illegal short cut and legal underpass in Ostrava-Kunčice.

\subsubsection{Třinec}

The railroad was brought to Třinec in 1871. Its location disrupted links and relationships between small structures of the scattered settlement (Figure 11). Later dynamic growth of the city, driven by industrial development, led to growth of built-up areas in close proximity to the railway. In terms of the landscape's long-term use, mainly arable land and permanent grasslands were occupied. Within this part of the investigated territory, individual and collective housing, public services (e.g., a hospital in the eastern part), and a huge colony of garages were the main developments. The requirement for safe movement of pedestrians and cyclists around and over the railway line was not optimally taken into account when planning spatial relationships and links. Railway trespassing in Třinec occurs on a series of illegal paths, mainly at emergency exits in noise barriers. Pedestrian-crossing infrastructure is insufficient and unsatisfactory. Relationships between the two parts of the town are strong, and trespassing is so frequent, common, and socially accepted that the municipal police have already given up on both surveillance and penalization (Figure 12). The target destinations of unauthorized crossing are varied, but the most common motivation is as a short cut between residence and workplace, services or shops.

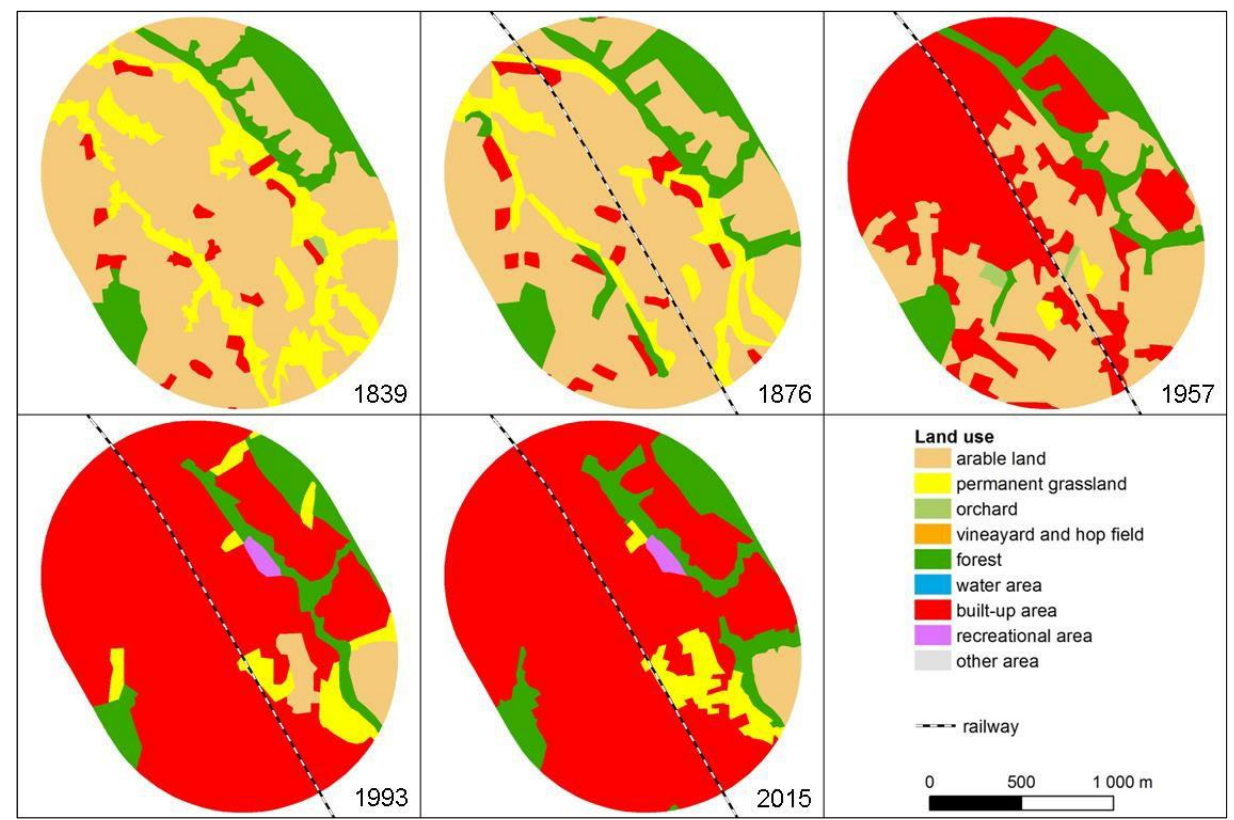

Figure 11. Development of land use and the railway network in Třinec. 

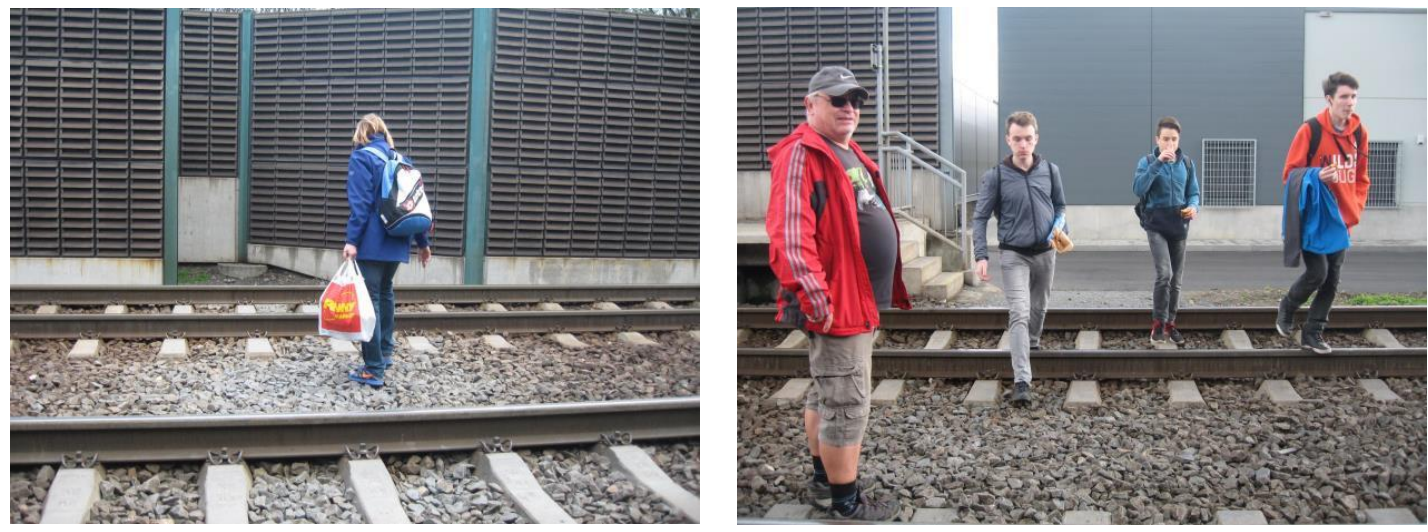

Figure 12. Trespassing in Třinec.

\subsection{Changes in Functional Land Use and Motivation for Crossing the Railway}

The motivations for inhabitants' movement between two or more fragmented parts of towns and municipalities were evaluated on the basis of a comparison of historical maps. A total of 33 different combinations were found in all the observed periods when comparing the category for functions of the built-up areas of functional division.

Although some railway sections in the study localities were opened already in 1841, during the 1836-1852 period such development did not impact the motivation for crossing the tracks. The reason was that the railways and railway stations were built outside of towns and did not directly enter built-up areas. Even in the following period 1876-1880, no significant restrictions of relationships and links between differently used areas were found on the topographical maps of most selected localities. The restrictions were identified only in nine cases and these mostly concerned relationships between mono-functional types of land use: between housing areas $(\mathrm{BI} \times \mathrm{BI})$ and between housing and industrial areas $(\mathrm{BI} \times \mathrm{VT}, \mathrm{BI} \times \mathrm{VL})$.

The topographic maps of the following period 1953-1955 show significantly more complex structures regarding functional division of areas, thus resulting also in more complex conditions for area development and especially for introducing railways into the territories. A detailed study of the topographic maps revealed the foundations of the links in the territories that often influence the motivation for trespassing even today. New phenomena in this period included the building up of such recreational areas as garden colonies (RZ) and the considerable expansion of collective housing areas. The structure of territorial patterns and spatial relationships was significantly influenced also by industrial areas (VT, VL).

The proportion of multi-functional areas significantly increased in the monitored localities during the period 1988-1991. Railway tracks and railway stations thus divided the territories with manifold representation of areas for housing $(\mathrm{BI}, \mathrm{BH})$, industry $(\mathrm{VT}, \mathrm{VL})$, and most recently also for public services (OX). On the outskirts of cities and at attractive tourist areas, crossing towards recreational areas and gardens became an important motivation for trespassing. Most of these motivations have been preserved to this day.

The relationships and links remain today relatively complex in the urban structure of the studied localities. Compared to the previous period, a new phenomenon is the increasing proportion of shopping areas (OK). The construction of such structures is often connected with the closure of industrial sites and processes of revitalizing brownfields. On the other hand, the relationships and links between housing areas (BI, BH) and industrial areas (VT, VL) have significantly decreased in some cases, as factories were closed or reduced their production, or, in some cases, even were replaced by other, less-frequented establishments. 


\section{Discussion}

The main purpose of this article is to describe how conflict points in urbanized areas are formed using available topographical maps, aerial images and town plans within a wider spatial context and while considering functional land use. Furthermore, the study proves a hypothesis relating to the impact of railway construction on the development of settlements and restriction of land permeability for pedestrians:

(a) in cases of a railway intersecting an existing settlement structure; and

(b) in cases of a railway built apart from the historical settlement structure and then gradually surrounded by built-up areas with various use functions.

The study of old topographical maps proved that this method can reveal the formational origins of railway-trespassing localities or at least the period in which current problems originated. At the same time, however, it was confirmed that motivations for railway trespassing are subject to constant change in dynamically developing urban areas. Recent changes are influenced particularly by the restructuring of industry in the Czech Republic after 1989 that was followed by the emergence of brownfield and revitalization efforts $[30,35]$. Revitalization of brownfield sites in the urban environment and its impact on functional land use in proximity to railways are also the subject of studies in other European countries [28,29]. A specific issue concerns mining areas, where the reduction, conservation, or expansion of mining activity is crucial for functional urban division. This problem was relevant in the study localities of Karviná and Ostrava-Kunčice. The reduction of mining significantly influenced the development potential of whole areas, including mining localities in proximity to railway tracks [36].

Restriction of territorial permeability for pedestrian movement was demonstrated in all territories where the railway was introduced into existing settlement structures. Original spatial relationships were severed, mainly due to the disruption of original streets or roads and disconnection of typical walking destinations like schools, places of work, and sports and cultural facilities. Even in cases when the railway was introduced outside built-up areas, optimal urban development respecting pedestrians' and cyclists' needs was not always achieved. Proximity of railway stations and accessibility of transport infrastructure often encouraged the construction and development of industrial sites, and their fenced-off buildings became barriers to pedestrians.

A particularly relevant phenomenon was the development of railway networks in dynamically changing regions, which was identified primarily in such mining and industrial areas as the Ostrava region [37]. The findings of this research are consistent with the results of research based on the study of old topographical maps and land use. In the cases of Ostrava-Vítkovice and Kunčice, the region was found to be very dynamic, with frequent changes in both the layout of the railway network itself and in land-use functions.

Among the sample of 27 localities monitored with regard to land use, high growth dynamics in built-up areas was observed in settlements of the industrial Ostrava region, some localities connected to Brno, and towns of regional importance (Hodonín, Vyškov). Similar trends of landscape use have also been recorded in other parts of the Czech Republic [17,18] or other countries [20,21,38,39] where the development of industrial and mining areas was accompanied by considerable growth of built-up and other areas within the given region. The mosaic of various functional area types, namely the combination of housing areas $(\mathrm{BI}, \mathrm{BH})$ with shopping $(\mathrm{OK})$, industrial (VT, VK), and public services infrastructure is the crucial factor shaping motivations for railway trespassing.

Recreational areas in valuable natural landscapes and areas used for suburban recreation with cottages and gardens constitute a special category among risk localities where trespassing occurs frequently. Among other reasons, illegal short cuts over railway tracks can be very highly frequented due to the great popularity of outdoor recreational activities in the Czech Republic (e.g., 26\% of inhabitants take part in hiking, walking, cyclotourism, cross-country skiing, or mushroom picking at least once per week, and there are about 500,000 weekend cottages in the Czech Republic). Changes in land use within these regions has not been very dynamic except for the development of recreational 
areas. A certain degree of landscape continuity with a high proportion of continuously used forest areas or permanent grasslands can be observed here [17,18,38,39].

\section{Conclusions}

Old topographic maps proved to be a useful source for detecting the original motives for the formation of potential conflict points where railway trespassing occurs. They also can serve to identify the period during which the problem emerged. With regard to long-term land use, high growth dynamics in built-up areas were recorded at almost all monitored localities. Built-up areas were usually formed at the expense of arable land and permanent grassland. Different trends in landscape use were found in the localities where recreational areas and suburban garden colonies exist. In recreational localities, the process of land-use change consists mostly in growth in holiday resorts, while valuable nature areas remain. Garden and orchard areas on the outskirts of towns are negatively impacted by suburbanization processes connected with the construction of commercial areas.

In most of the monitored localities, gaps were found in spatial planning regarding the possibilities for pedestrian movement in proximity to railways and in technical solutions for railway crossing. Whether intersecting existing settlement structures or gradually being surrounded by built-up areas, railway tracks became an obstacle for the logical daily trips of inhabitants.

The problem of railways' barrier effects has been underestimated in the past, and thus a large number of improvised, illegal and dangerous paths arose. To prevent the formation of new illegal short cuts in future, it is very important always to consider existing pedestrian relationships and potential impacts when planning changes in land use (building of new housing, shopping centres, schools, industrial plants) in the vicinity of railways or when designing new or relocated railways. It is necessary to draw attention to deficiencies in spatial planning and to require the inclusion of specific measures to improve the permeability of the railways. Effective measures include the construction of barrier-free underpasses which follow the most important pedestrian routes in a particular location.

Acknowledgments: This article was produced with financial support from the Ministry of Education, Youth and Sports within the National Sustainability Programme I, project of Transport R\&D Centre (LO1610), on research infrastructure acquired from the Operation Programme Research and Development for Innovations (CZ.1.05/2.1.00/03.0064).

Author Contributions: Pavlína Skládaná, Marek Havlíček, Ivo Dostál., Pavel Skládaný, Pavel Tučka designed the topic of the article; Pavel Skládaný, Pavlína Skládaná, Pavel Tučka, Jan Perůtka conducted field research; Marek Havlíček, Ivo Dostál analyzed geographical maps and maps of land use; Pavlína Skládaná, Marek Havlíček, Ivo Dostál wrote the paper.

Conflicts of Interest: The authors declare no conflict of interest.

\section{References}

1. Anonymous. Summary Report of the Traffic Accidents in the Czech Republic in 2015; Directorate of the Traffic Police of the Police Presidium of the Czech Republic: Praha, Czech Republic, 2016.

2. Havarneanu, G.M.; Burkhardt, J.; Paran, F. A systematic review of the literature on safety measures to prevent railway suicides and trespassing accidents. Accid. Anal. Prev. 2015, 81, 30-50. [CrossRef] [PubMed]

3. Havarneanu, G.M.; Bonneau, M.H.; Colliard, J. Lessons learned from the collaborative European project RESTRAIL: REduction of Suicides and Trespasses on RAILway property. Eur. Transp. Res. Rev. 2016, 8, 1-15. [CrossRef]

4. Silla, A.; Vainiomäki, V. Feasibility Study on the Use of Spatial Analysis in the Prevention of Rail TrainTrespasser Collisions: Effective Recommendations for Level Crossing Safety with Theme Investigation. In Proceedings of the 14th Global Level Crossing Safety and Trespass Prevention Symposium, Helsinki, Finland, 12-16 June 2016.

5. Silla, A.; Luoma, J. Trespassing on Finnish railways: Identification of problem sites and characteristics of trespassing behaviour. Eur. Transp. Res. Rev. 2008, 1, 47-53. [CrossRef]

6. Silla, A.; Luoma, J. Opinions on railway trespassing of people living close to a railway line. Saf. Sci. 2012, 5, 62-67. [CrossRef] 
7. Burkhardt, J.M.; Radbo, H.; Silla, A.; Paran, F. A Model of Suicide and Trespassing Processes to Support the Analysis and Decision Related Top Reventing Railway Suicides and Trespassing Accidents at Railways. In Proceedings of the Transport Research Arena, Paris, France, 14-17 April 2014; Available online: https://www.researchgate.net/publication/259381506_A_model_of_suicide_and_trespassing_processes_ to_support_the_analysis_and_decision_related_to_preventing_railway_suicides_and_trespassing_ accidents_at_railways (accessed on 30 December 2017).

8. Lobb, B.; Harre, N.; Suddendorf, T. An evaluation of suburban railway pedestrian crossing safety programme. Accid. Anal. Prev. 2001, 33, 157-165. [CrossRef]

9. RSSB. Annual Safety Performance Report 2013/2014; Rail Safety and Standards Board: London, UK, 2014.

10. Da Silva, M.P. Railroad Infrastructure Trespass Detection Performance Guidelines; Final Report No. DOT/FRA/ ORD-11/01a; Federal Railroad Administration: Washington, DC, USA, 2011.

11. Özdogan, M.; Cakar, S.; Ağalar, F.; Eryilmaz, M.; Aytaç, B.; Aydinuraz, K. The epidemiology of the railway related casualties. Turk. J. Trauma Emerg. Surg. 2006, 12, 235-241.

12. Stefanova, T.; Burkhardt, J.M.; Wullems, C.H.; Freeman, J.; Rakotonirainy, A.; Delhomme, P. Direct Observations of Pedestrian Unsafe Crossing at Urban Australian Level Crossings. Urban Rail Transit 2015, 1, 112-130. [CrossRef]

13. Freeman, J.; Rakotonirainy, A. Mistakes or deliberate violations? A study into the origins of rule breaking at pedestrian train crossings. Accid. Anal. Prev. 2015, 77, 45-50. [CrossRef] [PubMed]

14. Skládaná, P.; Skládaný, P.; Tučka, P.; Bidovský, M. Trespassing railway property-typology of risk localities. Transp. Res. Procedia 2016, 14, 2091-2100. [CrossRef]

15. Savage, I. Trespassing on the rail road. Railr. Econ. 2007, 2, 199-224. [CrossRef]

16. Skaloš, J.; Weber, M.; Lipský, Z.; Trpáková, I.; Šantrůčková, M.; Uhlířová, L.; Kukla, P. Using old military survey maps and orthophotograph maps to analyse long-term land cover changes-Case study (Czech Republic). Appl. Geogr. 2011, 31, 426-438. [CrossRef]

17. Skokanová, H.; Havlíček, M.; Borovec, R.; Demek, J.; Eremiášová, R.; Chrudina, Z.; Mackovčin, P.; Rysková, R.; Slavík, P.; Stránská, T.; et al. Development of land use and main land use change processes in the period 1836-2006: Case study in the Czech Republic. J. Maps 2012, 8, 88-96. [CrossRef]

18. Havlíček, M.; Chrudina, Z. Long-term land use changes in relation to selected relief characteristics in Western Carpathians and Western Pannonian basin-case study from Hodonín District (Czech Republic). Carpath. J. Earth Environ. Sci. 2013, 8, 231-244.

19. Havlíček, M.; Dostál, I. Land use dynamics in the Hodonín district in the context of historical development of transport network. Acta Pruhon. 2012, 102, 57-64.

20. Colonna, P.; Berloco, N.; Circella, G. The Interaction between Land Use and Transport Planning: A Methodological Issue. Procedia Soc. Behav. Sci. 2012, 53, 84-95. [CrossRef]

21. Cervero, R. Linking urban transport and land use in developing countries. J. Transp. Land Use 2013, 6, 7-24. [CrossRef]

22. DeVos, J.; Witlox, F. Transportation policy as spatial planning tool; reducing urban sprawl by increasing travel costs and clustering infrastructure and public transportation. J. Transp. Geogr. 2013, 3, 117-125. [CrossRef]

23. Keken, Z.; Kušta, T.; Langer, P.; Skaloš, J. Landscape structural changes between 1950 and 2012 and their role in wildlife-vehicle collisions in the Czech Republic. Land Use Policy 2016, 59, 543-556. [CrossRef]

24. Havlíček, M. Influence of Transportation on Landscape Changes. In Proceedings of the III Czech-Slovak Conference "Transport, Health and Environment", Litomyšl, Czech Republic, 4-5 November 2008; Adamec, V., Dostál, I., Eds.; Centrum dopravního výzkumu: Brno, Czech Republic, 2008; pp. 119-126.

25. Kasraian, D.; Maat, K.; Stead, D.; van Wee, B. Long-term impacts of transport infrastructure networks on land-use change: An international review of empirical studies. Transp. Rev. 2016, 36, 772-792. [CrossRef]

26. Alvarez, E.; Franch, X.; Marti-Henneberg, J. Evolution of the Territorial Coverage of the Railway Network and its Influence on Population Growth: The Case of England and Wales, 1871-1931. Hist. Methods 2013, 46, 175-191. [CrossRef]

27. Noonan, D.S. Neighbours, Barriers and Urban Environments: Are Things "Different on the Other Side of Tracks"? Urban Stud. 2005, 42, 1817-1835. [CrossRef] 
28. Bartke, S.; Martinát, S.; Klusáček, P.; Pizzol, L.; Alexandrescu, F.; Frantál, B.; Critto, A.; Zabeo, A. Targeted selection of brownfields from portfolios for sustainable regeneration: User experiences from five cases testing the Timbre Brownfield Prioritization Tool. J. Environ. Manag. 2006, 1, 94-107. [CrossRef] [PubMed]

29. Tintěra, J.; Ruus, A.; Tohvri, E.; Kotval, Z. Urban brownfields in Estonia: Scope, consequences and redevelopment barriers as perceived by local governments. Morav. Geogr. Rep. 2014, 22, 25-38.

30. Krejčí, T.; Dostál, I.; Havlíček, M.; Martinát, S. Exploring the hidden potential of sugar beet industry brownfields (case study of the Czech Republic). Transp. Res. Part D Transp. Environ. 2016, 46, $284-297$. [CrossRef]

31. Kubeček, J. Special Electronic Map of Train-Person Crashes. Transport Research Centre [Centrum Dopravního Výzkumu]. 2015. Available online: http://www.cdv.cz/ kubecek/amelia/index.php (accessed on 30 December 2017).

32. Hudec, Z. Atlas of Railways of the Czech Republic 2006-2007; Dopravní Vydavatelství Malkus: Prague, Czech Republic, 2006.

33. Mackovčin, P. Land use categorization based on topographic maps. Acta Pruhon. 2009, 91, 5-13.

34. Dostál, I.; Havlíček, M.; Huzlík, J. Evaluation of Transport Impact to the Landscape. In Proceedings of the IV Czech-Slovak Scientific Conference “Transport, Health and Environment”, Blansko, Czech Republic, 2-3 November 2010; Adamec, V., Jandová, V., Eds.; Tribun EU: Brno, Czech Republic, 2010; pp. 97-104.

35. Havlíček, M.; Svoboda, J.; Dostál, I. Development of Sugar Industry in Hodonín district and its Effect on Land-use changes and Transport Infrastructure. Listy Cukrov. Řepařské 2013, 129, 312-316.

36. Martinát, S.; Navrátil, J.; Dvořák, P.; Klusáček, P.; Kulla, M.; Kunc, J.; Havlíček, M. The expansion of coalmining in the depression areas-Away to development? Hum. Geogr. 2014, 8, 5-15. [CrossRef]

37. Zapletalová, J. Development of railway traffic and the network of sidings in the Ostrava region. Morav. Geogr. Rep. 2006, 14, 60-68.

38. Liga, J.; Petrovič, F.; Boltižiar, M. Land cover changes in Slovakia 1990-2006 related to the distance from industrial areas and economic development. Geogr. Čas. 2014, 66, 3-20.

39. Súl'ovský, M.; Falt'an, V. Analysis of land use changes and their relations to topographic factors: Case study of the municipality Lietavská Svinná-Babkov. Geogr. Čas. 2015, 67, 45-62.

(C) 2018 by the authors. Licensee MDPI, Basel, Switzerland. This article is an open access article distributed under the terms and conditions of the Creative Commons Attribution (CC BY) license (http:/ / creativecommons.org/licenses/by/4.0/). 